\title{
GAAP versus The Street: An Empirical Assessment of Two Alternative Definitions of Earnings
}

\author{
MARK T. BRADSHAW* AND RICHARD G. SLOAN
}

Received 31 December 1999; accepted 8 October 2001

\begin{abstract}
Managers, security analysts, investors, and the press rely increasingly on modified definitions of GAAP net income, known by such names as "operating" and "pro forma" earnings. We document this phenomenon and discuss competing explanations for the recent rise in the use of such modified earnings numbers and implications for the interpretation of related accounting research. Our results show that over the past 20 years there has been a dramatic increase in the frequency and magnitude of cases where "GAAP" and "Street" earnings differ. Further, there is a very strong bias toward the reporting of a Street earnings number that exceeds the GAAP earnings number. We also show that the market response to the Street earnings number has displaced GAAP earnings as a primary determinant of stock prices. Finally, through an analysis of earnings releases, we show that management has taken a proactive role in defining and emphasizing the Street number when communicating to analysts and investors.
\end{abstract}

\footnotetext{
* Harvard Business School; $\dagger$ University of Michigan. We acknowledge the helpful comments of Mark Bagnoli, Ramji Balakrishnan, Larry Brown, Ilia Dichev, Bruce Johnson, Richard Leftwich (the Editor), Sonja Olhoft, Scott Richardson, Rick Tubbs, an anonymous reviewer, and seminar participants at the University of Iowa. We also thank $I / B / E / S$ International Inc. for providing data on analyst earnings estimates and other information.
} 


\section{Introduction}

Since the seminal work of Ball and Brown [1968], it has been well documented that stock prices are closely related to earnings performance. Earnings performance has been traditionally measured using the net income and earnings per share (EPS) figures produced according to "generally accepted accounting principles" (GAAP). However, recent years have witnessed an increasing focus on "Street" earnings numbers, which are the numbers announced by corporations in their press releases and tracked by analyst estimate clearinghouse services, such as $I / B / E / S$, Zacks, and First Call.

In this paper, we present evidence that a growing rift has developed between GAAP earnings numbers and Street earnings numbers. We show that this rift has arisen because both management and the analyst tracking services increasingly focus on Street measures of earnings, excluding a variety of expenses required under GAAP. This rift has been exaggerated by a dramatic increase in the magnitude and frequency of expenses that are being excluded from Street earnings (e.g., "special items" and "non-cash items"). We also provide evidence that investors price the Street earnings numbers reported by the analyst tracking services, rather than the earnings numbers reported under GAAP. Finally, we provide evidence suggesting that the increased attention on the alternative definitions of earnings is driven by the reporting strategies of firm managers.

Our results are consistent with two interpretations. First, the increased emphasis on Street earnings may represent an attempt by managers and analysts to garner higher valuations by reporting the higher Street earnings numbers. While difficult to reconcile with traditional academic theories such as the efficient market hypothesis, this interpretation is consistent with those provided by the financial press. ${ }^{1}$ This perspective also corroborates recent concerns raised by Arthur Levitt, former Chairman of the Securities and Exchange Commission. ${ }^{2}$ The second interpretation is that the increased emphasis on Street earnings may represent attempts by managers and analysts to remove transitory components from earnings in order to make Street earnings an improved measure for determining future cash flows and hence firm value. Both analysts and academics have long focused on the identification of permanent versus transitory components of earnings. For example, Barnea, Ronen, and Sadan [1975] discuss extraordinary item classification and argue that "the primary criterion is whether management, which is in the best position to assess the recurrability of earnings, believes the item to be transitory or persistent" (p. 63). This is the perspective advocated in related working papers by Abarbanell and Lehavy [2000] and Brown and

\footnotetext{
${ }^{1}$ See, for example, "Companies Use Every Trick to Pump Earnings and Fool Investors. The Latest Abuse: ‘Pro Forma’ Reporting,” David Henry, BusinessWeek, May 14, 2001.

${ }^{2}$ See "The Numbers Game," by A. Levitt, unpublished remarks available at http://www. sec.gov/news/speeches/spch220.txt.
} 
Sivakumar [2001]. These two interpretations are not mutually exclusive, and given the recency of the Street earnings phenomenon, we are currently unable to provide conclusive evidence on the relative importance of these competing explanations.

Regardless of the interpretation of the results, our findings have a number of important implications for existing research. First, our findings are relevant to the interpretation of recent work that documents a reduction in the optimism of analysts' forecasts (e.g., Matsumoto [2000], Brown [2001], Richardson, Teoh, and Wysocki [2000]). That research generally concludes that the decline in optimism is due to management's downward guidance of analysts' forecasts. Alternatively, we show that the Street earnings numbers tracked by analysts have been increasingly inflated by the exclusion of a growing number of charges. The combined effect of downward guidance of analysts' forecasts by managers and inflation of the "actual" earnings number reported on the analyst tracking databases translates into a decline in the ex post optimism of analysts' forecasts. In other words, there appears to have been a convergence between the numbers being forecasted by analysts and the numbers that the databases archive as earnings, although these alternative earnings figures differ from what has customarily been identified as "net income" (i.e., GAAP). Thus, our findings are relevant to any research that draws inferences based on a time-series of forecast errors.

Second, our results also have implications for recent academic research investigating temporal trends in the value relevance of earnings (e.g., Collins, Maydew, and Weiss [1997], Francis and Schipper [1999], Chang [1999]). This research generally documents a decline in the association between GAAP earnings and stock prices and concludes that there has been a decline in the value relevance of earnings. In contrast, we show that there has been a dramatic increase in the association of Street earnings with stock prices. Thus, our results extend this line of research and suggest that the market focuses on the modified Street definition of earnings rather than GAAP earnings.

Finally, our results complement a number of studies that consider alternatives to classical earnings management (Healy and Wahlen [1999]). For example, Schrand and Walther [2000] investigate whether managers affect the benchmark against which current earnings are judged by strategically "reminding" investors about transitory gains and losses. Our findings are related, and one interpretation of them is that managers have also adopted another subtle approach by successfully creating modified definitions of earnings that are generally higher than GAAP earnings. This phenomenon is related to the work on classificatory income smoothing by Barnea, Ronen, and Sadan [1976], who argue that managers employ extraordinary items classification to reduce over-time variation in operating income. Specifically identifying charges to be excluded from Street earnings is less restrictive than classificatory smoothing, however, because management need not actually segregate in the financial statements the charges excluded. 


\section{Development of Empirical Predictions}

The quarterly earnings announcement season has become a closely watched ritual. Wall Street analysts and corporate management engage in an increasingly complex game with investors, where even small negative earnings surprises can result in huge negative stock returns. ${ }^{3}$ As a consequence, corporate managers have adopted a number of techniques to avoid reporting negative surprises, including earnings pre-announcements and other expectations management strategies (e.g., Kasznik and Lev [1995], Matsumoto [2000]).

We investigate another potential technique for reporting earnings news to investors, whereby the reported earnings are modifications of GAAP earnings such that certain expenses deemed to be "non-recurring" or "non-cash" are excluded. Sell-side analyst tracking services (i.e., First Call, $I / B / E / S$, and Zacks) act as the arbiters of the magnitude of earnings surprises, and appear to be increasingly following the lead of management and analysts in excluding ever more charges from earnings. A recent Wall Street Journal article describes the process as follows: ${ }^{4}$

Analysts report to First Call earnings estimates based on "operating" earnings, which is regular income that doesn't include the costs for one-time charges, for things like mergers. First Call then uses those numbers to calculate consensus earnings estimates. But there's a hitch. There's no definition of operating earnings in accounting rules. So companies increasingly leave out of the so-called operating or pro forma earnings pot many more charges. These include employee stock-based compensation and goodwill, the premium acquiring companies pay over a target company's book value.

"What companies are trying to do is entice analysts into excluding certain charges and value them only on that basis," Mr. Hill says. In effect, "companies are creating their own grading systems to help ensure that, no matter how their business is doing, they will get an A or an A+," says accounting expert Howard Schilit.

Examples of charges that are regularly excluded from the Street's definition of reported earnings include restructuring charges, write-downs and impairments, research and development expenditures, merger and acquisitions costs, mandatory stock compensation expense, goodwill amortization, and certain results of subsidiaries. ${ }^{5}$ Note the absence of revenues from this

\footnotetext{
${ }^{3}$ See Skinner and Sloan [1999] for evidence on the asymmetry of price reactions to small negative relative to small positive earnings surprises. Alternatively, Kinney, Burgstahler, and Martin [2000] document that, although price reactions to negative (positive) earnings surprises are reliably negative (positive), such reactions are not always "probable," where they assume probable means "a likelihood of .75 or higher."

${ }^{4}$ See "Varied Profit Reports by Firms Create Confusion," by Elizabeth MacDonald, The Wall Street Journal, August 24, 1999, p. C1.

${ }^{5}$ In contrast to employee stock options, for which the FASB encourages but does not require expense treatment (SFAS No. 123), firms exclude certain other stock-based charges that are classified as expenses under GAAP such as payroll taxes on stock options, stock appreciation rights, variable stock options, and acquisition-related costs classified as compensation, as well as certain deferred compensation and severance arrangements.
} 
list. ${ }^{6}$ A case in point is Amazon, which reports "pro forma" earnings that "exclude amortization of goodwill and other intangibles, equity in losses of equity-method investees, stock-based compensation costs, and merger, acquisition and investment-related costs," and more recently expanded this list to include interest expense on long-term debt. ${ }^{7}$ However, despite excluding equity method losses, Amazon's pro forma earnings include revenue associated with noncash transactions whereby equity-method investees exchange equity securities for advertising and promotional services. ${ }^{8}$ Motivated by seemingly pervasive anecdotal evidence, we seek to document the magnitude of the growing rift between Street earnings and GAAP earnings and to identify some of the major causes and consequences of this rift.

The concepts of consensus earnings and earnings surprise relative to consensus are relatively new, and were not pervasive on Wall Street until the early 1990 s. $^{9}$ The analyst tracking services have increasingly promulgated these concepts over the past decade. By working with management and analysts to create a new language and system for summarizing and disseminating earnings information, the analyst tracking services have become an integral aspect of managerial disclosure of quarterly earnings. Our basic prediction is that the phenomenon of reporting Street rather than GAAP earnings has become more pervasive over the last decade, along with the rise to prominence of analyst tracking services. Our first prediction is:

P1: The magnitude of the difference between Street earnings as reported by the analyst tracking services and GAAP earnings as reported in firms' financial statements has been growing over the last decade.

To establish the economic significance of differences between Street and GAAP earnings, we investigate the relative ability of forecast errors computed using the two definitions of earnings to explain contemporaneous stock returns. If either (i) investors are misled by managers' focus on Street earnings or (ii) expenses and charges excluded from Street earnings are indeed transitory with no implications for future earnings, stock returns should be more highly associated with Street-based forecast errors than GAAP-based forecast errors. Formally stated,

P2: Stock returns are more highly associated with Street earnings than with GAAP earnings.

\footnotetext{
${ }^{6}$ SEC Chief Accountant Lynn Turner has recently referred to Street earnings as "EBS earnings," for "Everything but Bad Stuff."

${ }^{7}$ Company press release from Business Wire, April 26, 2000, "Amazon.com Surpasses 20 Million Cumulative Customer Accounts and Announces Financial Results for First Quarter 2000."

${ }^{8}$ To quantify these effects, in the first quarter of 2000 , Amazon reported a Street loss of 35 cents per share versus a GAAP loss of 90 cents per share, with the Street loss "beating" analysts' estimates by one cent.

${ }^{9}$ See "The Trouble with the Consensus Estimate," Joseph Nocera, Money Magazine, June 1, 1998.
} 
Tests of this prediction will provide prima facie evidence as to which earnings measure investors view as more value relevant. However, this test does not provide definitive conclusions regarding the extent to which investors should ignore expenses and charges excluded from Street earnings. Such a test would require us to identify the future date at which investors realize that the excess of Street earnings over GAAP earnings will not result in a corresponding cash flow or dividend. Given that the divergence between Street earnings and GAAP earnings is a relatively recent phenomenon, we do not have a long enough history to construct powerful tests of this hypothesis. However, indirect evidence on this issue is provided in a recent working paper by Burgstahler, Jiambalvo, and Shevlin [1999]. They demonstrate that security prices act as if investors do not fully impound the time-series properties of negative special items, which anecdotally appear to be among charges routinely excluded from Street earnings.

With respect to the first two predictions, we expect that the growing difference between Street earnings and GAAP earnings is attributable to both an increase in the frequency of the type of costs excluded from Street earnings and an increased tendency of the analyst tracking services to exclude such costs from Street earnings. A large number of the charges that are excluded from Street earnings are coded by Compustat as "special items," and include restructuring charges, asset impairments, merger and acquisition charges and other significant non-recurring items. There are numerous other charges that might also be considered, such as amortization expense and losses of certain subsidiaries. However, we wish to focus on special items for several reasons. First, the use of special items by managers to affect market perceptions of their performance is well established in the literature (e.g., Elliott and Hanna [1996], Kinney and Trezevant [1997], and others). Second, special items are separately and consistently coded by Compustat, thus facilitating data collection. Finally, we believe that the exclusion of the other charges by the Street is a much more recent and selective phenomenon than the exclusion of special items, and including them may introduce noise and lead to a lack of power. ${ }^{10}$ Thus, we focus our predictions and tests on special items. The third and fourth predictions follow:

P3: There has been an increase in the relative frequency of negative special items over the past decade.

P4: There has been an increased tendency of the analyst tracking services to report earnings before negative special items over the past decade.

Evidence on the increasing frequency of negative special items is documented in several recent studies (e.g., Elliott and Hanna [1996]). In an

\footnotetext{
${ }^{10}$ In supplemental tests, we use annual data and analyze other charges that seem to be frequently excluded from Street earnings, including amortization expense, research and development expense, and nonoperating income. These tests are discussed in the results.
} 
earlier paper, Philbrick and Ricks [1991] examine discrepancies between earnings per share across several research databases during 1984-1986 (Value Line, I/B/E/S, Standard \& Poor's, Zacks, and Compustat). They find differences across the databases and conclude that the choice of earnings per share, rather than the choice of forecasted earnings, has a significant impact on empirical associations between forecast errors and stock returns. Our tests extend this evidence by examining temporal changes in the extent to which special items are excluded from Street earnings.

Clearly, managers are responsible for the timing and amount of recorded special items. What is unclear, however, is whether an explicit focus on Street definitions of earnings originates with managers or analysts. Managers have numerous incentives to report higher earnings (Healy and Wahlen [1999]), but managers also possess inside information regarding future recurring earnings (Barnea, Ronen, and Sadan [1975]). Both ideas are consistent with managers having spawned the notion of Street earnings. Anecdotal evidence also indicates managers are proactive in encouraging analysts to exclude ever more charges from earnings. For example, Chuck Hill, First Call's research chief, states, "It's snowballing-we're seeing more and more companies reporting their earnings in numerous different ways, and analysts are going along with it." 11 In a recent and well-publicized example, Staples, Inc. persuaded analysts to prepare forecasts excluding the losses from its Staples.com division. ${ }^{12}$ Moreover, the reporting of Street versus GAAP earnings seems biased to present results in a more favorable light. For example, in 1998 Network Associates announced,

"Excluding non-recurring charges associated with acquisitions, pro forma fully diluted earnings per share increased $64 \%$ to $\$ .41$ compared with pro forma fully diluted earnings per share of $\$ .25$ in the second quarter of 1997. Including non-recurring charges associated with acquisitions, reported fully diluted earnings (loss) per share was $\$(.87)$ compared with $\$ .25$ in the same period last year." ${ }^{3}$

Note that "pro forma" earnings per share for the prior year were equal to GAAP earnings per share, and moreover, that the pro forma earnings per share suggest an upward trend in earnings versus a reversal from profitability to losses according to the GAAP figures. Our final prediction directly links the focus on Street earnings to managerial guidance:

P5: Over the past decade, managers have increased their emphasis on Street definitions of earnings in their quarterly earnings announcements.

\footnotetext{
${ }^{11}$ See Elizabeth MacDonald, op. cit.

12 "No Accounting for the Net?," by Laura Johannes, The Wall Street Journal, May 19, 2000, p. C1.

${ }^{13}$ PR Newswire, July 20, 1998.
} 


\section{Data}

Data used in this study are obtained from the $I / B / E / S$, Compustat (quarterly), and CRSP (daily) research tapes. We focus on quarterly earnings per share because prior evidence demonstrates the importance of these announcements for stock prices (e.g., Skinner and Sloan [1999]) and reveals that the incidence of write-offs and other one-time items differs across fiscal quarters (Burgstahler, Jiambalvo, and Shevlin [1999]). Based on this research, we anticipate that the largest differences between Street and GAAP earnings will occur during the fourth fiscal quarter. We use $I / B / E / S$ to obtain the measure of earnings reported by the analyst tracking services. $I / B / E / S$ represents only one of the three major analyst tracking services. With respect to the other two, we do not have Zacks data available in machine-readable form, and First Call has a relatively short history of data, making it unsuitable for our tests. From $I / B / E / S$, we obtain forecasted quarterly earnings per share and $I / B / E / S$-defined earnings per share. The sample period is $1985-$ 1997. We begin with 1986 because coverage on $I / B / E / S$ is limited for earlier years. To be consistent with the forecasts, data on stock prices for scaling are also obtained from $I / B / E / S$. GAAP earnings per share, earnings announcement dates, and certain accounting data (e.g., special items, total expenses, etc.) are obtained from Compustat. Finally, common stock returns for quarterly earnings announcement periods (described below) are obtained from the CRSP daily returns file.

The initial sample with complete Compustat and $I / B / E / S$ data consists of 108,864 firm-quarter observations. The number of observations available in each year ranges from 4,919 in 1985 to 14,179 in 1997 . Within each year, the distribution of observations is approximately equal across the four fiscal quarters. In later tests using stock returns, the sample size is reduced to 98,647 firm-quarter observations due to missing return data on CRSP.

GAAP earnings per share from Compustat ("EPS $\mathrm{GAAP}_{\text {") }}$ reflect income before extraordinary items (quarterly data item \#8) divided by the average common shares outstanding during the quarter (data item \#61) adjusted for stock splits (data item \#17). Note that this definition of earnings excludes both extraordinary items and earnings from discontinued operations, which is not bottom-line net income. We adopt income before extraordinary items because the latitude available to managers in classifying expenses and charges as "extraordinary" is restricted to a limited number of events that qualify as unusual and infrequent. Further, including earnings from discontinued operations and cumulative effects of accounting changes in our GAAP earnings number would add noise to our tests without contributing towards the testing of our predictions. Additionally, we know that $I / B / E / S$ earnings per share ("EPS Street") reflect a company's earnings per share reported on a "continued operations" basis. $I / B / E / S$ defines this measure as follows $(I / B / E / S[1996])$ :

“...I $I / B / E / S$ receives an analyst's forecast after discontinued operations, extraordinary charges, and other non-operating items have been backed out. While this is far and away the best method for valuing a company, it often 
causes a discrepancy when a company reports earnings. $I / B / E / S$ adjusts reported earnings to match analysts' forecasts on both an annual and quarterly basis. This is why $I / B / E / S$ actuals may not agree with other published actuals; i.e., Compustat."

Thus, like our GAAP measure of net income, the $I / B / E / S$ definition also excludes extraordinary items and earnings from discontinued operations. But in addition, it also excludes "other non-operating items." Our hypotheses predict that $I / B / E / S$ has been more aggressively excluding such items from their definition of earnings.

To facilitate cross-sectional analysis, we scale both earnings per share figures by stock price during the last month of the fiscal quarter. The other key accounting variable in our analysis is special items (data item \#32), stated on an adjusted per share basis, which represents significant nonrecurring items other than extraordinary items or discontinued operations. This data item should capture a large fraction of the "non-operating items" that are excluded from earnings by $I / B / E / S$. However, in situations where firms include such charges within other income statement line items (e.g., "costs of goods sold," "depreciation and amortization" or "other operating expenses") and $I / B / E / S$ screens these amounts from their definition of earnings, the $I / B / E / S$ definition will exclude additional items. $I / B / E / S$ may be more active at screening out amounts that are included within other line items because of their stated efforts to adjust reported earnings to match analysts' forecasts.

We define quarterly forecast errors as reported earnings minus median consensus forecasted earnings, scaled by stock price (all data from the last month of the fiscal quarter). We calculate two different forecast errors using the two reported earnings per share measures, $\mathrm{EPS}_{\mathrm{GAAP}}$ and $\mathrm{EPS}_{\text {Street }}$, and we denote the forecast errors as $\mathrm{FE}_{\mathrm{GAAP}}$ and $\mathrm{FE}_{\text {Street }}$.

Finally, we measure long window stock returns between earnings announcement dates. Earnings announcement dates are obtained from the Compustat quarterly research tape. We define the long window return interval as the period beginning two days after the last quarterly earnings announcement and ending on the day after the current period earnings announcement. This interval averages approximately 60 trading days, and captures the effects of any earnings pre-announcements leading up to the earnings announcement. We use this interval because prior research documents that firms with negative earnings surprises are more likely to preannounce earnings and do so within two weeks of fiscal quarter end (Skinner [1997]). Use of a shorter window may miss pre-announcements for some firms, possibly biasing our results for firms with negative earnings surprises.

\section{Results}

\subsection{DESCRIPTIVE EVIDENCE}

We begin by presenting descriptive evidence that highlights the overall differences between GAAP and Street earnings over the last decade. Panels 
Panel A: Quarter 1

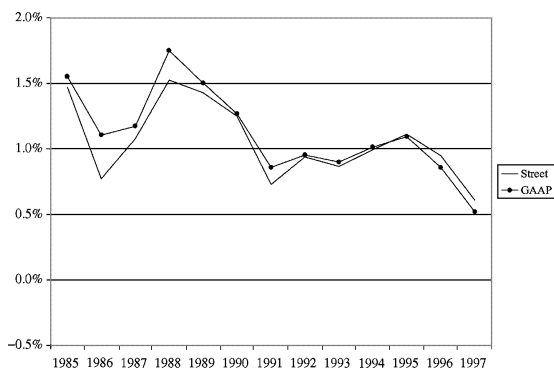

Panel C: Quarter 3

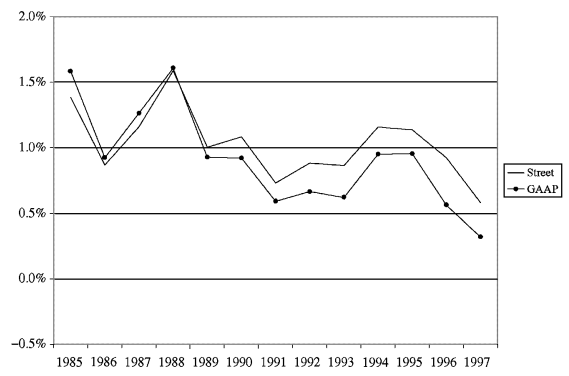

Panel B: Quarter 2

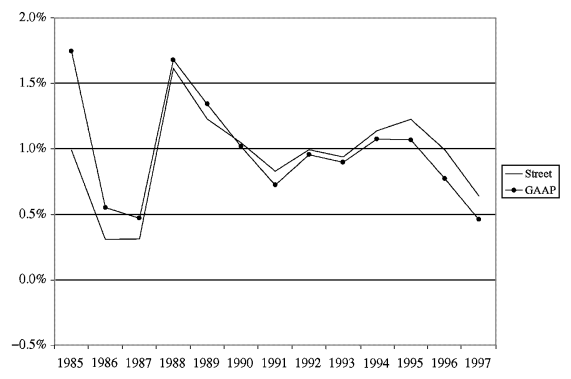

Panel D: Quarter 4

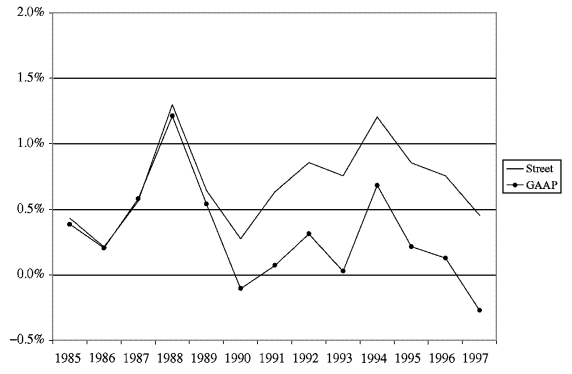

GAAP earnings are obtained from Compustat and are defined as earnings before extraordinary items and discontinued operations (data item \#25) divided by average common shares outstanding (data item \#61) adjusted for stock splits (data item \#17). Street earnings are obtained from $I / B / E / S$ and reflect GAAP earnings per share adjusted for certain charges considered by $I / B / E / S$ to be nonrecurring. Both earnings per share numbers are scaled by stock price, obtained from $I / B / E / S$ as of the final month of the firm's fiscal quarter end.

FIG. 1.-Comparative plots of quarterly cross-sectional means of earnings per share as a percentage of stock price for street and GAAP definitions of earnings, 1985-1997.

A through $\mathrm{D}$ of figure 1 plot quarterly earnings scaled by stock price over the period 1985-1997 for both $\mathrm{EPS}_{\mathrm{GAAP}}$ and EPS Street $_{\text {. The plots demonstrate }}$ the increasing disparity between these earnings per share definitions, and differences are significant (formal statistical tests are deferred). Although the most notable differences appear in the fourth quarter, all quarters indicate at least a slight disparity between EPS $_{\mathrm{GAAP}}$ and $\mathrm{EPS}_{\mathrm{Stree}}$ that has been growing in recent years. In particular, prior to the 1990s, reported earnings per share under the two definitions track each other reasonably well. However, beginning in the 1990s, there is a change in the relation between Street and GAAP earnings per share. ${ }^{14}$

\footnotetext{
${ }^{14}$ We spoke with an $I / B / E / S$ official, who agreed that $I / B / E / S$ indeed "stepped up" its adjustments to earnings around this time, because they were concerned about providing earnings figures that were consistent with analysts' forecasts and with the earnings supposedly followed by investors. This change in the calculation of earnings by $I / B / E / S$ is relevant to research on intertemporal changes in analyst bias or optimism, and is discussed later.
} 


\subsection{LONG WINDOW EARNINGS-RETURNS ASSOCIATION TESTS}

The evidence in figure 1 raises the issue of which definition of earnings capital market participants are paying attention to, the GAAP earnings figure or the Street earnings figure? To establish the degree to which the market is impounding each definition of earnings in prices, we investigate long window associations between stock returns and each definition of earnings. If the market finds Street earnings to be a better summary measure of performance, contemporaneous returns will be more highly correlated with $\mathrm{EPS}_{\text {Street }}$ than with $\mathrm{EPS}_{\mathrm{GAAP}}$.

In univariate analyses (not reported), we find that Street forecast errors are more highly correlated with stock returns than are GAAP forecast errors, which may not be surprising because we have shown that Street earnings exclude special items that are generally regarded as transitory. The following stock returns tests highlight the impact our findings may have on other results reported in the literature. We investigate whether the differences in the two definitions of forecast error have significantly different explanatory power with respect to long window stock returns across time, followed by a brief discussion of implications for recent studies on changes in the value relevance of accounting numbers.

Table 1 presents the results of regressions of long window returns on forecast errors. The regression is estimated separately for $\mathrm{EPS}_{\text {Street }}$ and $\mathrm{EPS}_{\mathrm{GAAP}}$

T A B L E 1

The Association Between Long Window Stock Returns and Street-based and GAAP-based Forecast Errors, 1985-1997 ( $n=98,647$ firm-quarters, $t$-statistics and ( $p$-values) under coefficient estimates)

\begin{tabular}{|c|c|c|c|c|c|c|c|}
\hline \multirow[b]{2}{*}{ Model } & \multicolumn{6}{|c|}{$\begin{aligned} \text { Return }= & \alpha_{0}+\alpha_{1} \text { POST92 }+\alpha_{2} \mathrm{FE}_{\text {Street }}+\alpha_{3} \mathrm{FE}_{\text {Street }} * \text { POST92 } \\
& +\alpha_{4} \mathrm{FE}_{\mathrm{GAAP}}+\alpha_{5} \mathrm{FE}_{\mathrm{GAAP}} * \text { POST } 92+\varepsilon\end{aligned}$} & \multirow[b]{2}{*}{ Adj. $R^{2}$} \\
\hline & Intercept & POST92 & $\mathrm{FE}_{\text {Street }}$ & $\begin{array}{l}\mathrm{FE}_{\text {Street }} * \\
\text { POST92 }\end{array}$ & $\mathrm{FE}_{\mathrm{GAAP}}$ & $\begin{array}{c}\mathrm{FE}_{\mathrm{GAAP}} * \\
\text { POST92 }\end{array}$ & \\
\hline 1 & $\begin{array}{c}0.043 \\
36.9 \\
(0.0001)\end{array}$ & $\begin{array}{c}0.008 \\
5.0 \\
(0.0001)\end{array}$ & $\begin{array}{c}0.567 \\
23.8 \\
(0.0001)\end{array}$ & $\begin{array}{c}1.248 \\
25.7 \\
(0.0001)\end{array}$ & - & - & 0.0241 \\
\hline 2 & $\begin{array}{c}0.044 \\
37.3 \\
(0.0001)\end{array}$ & $\begin{array}{c}0.008 \\
5.3 \\
(0.0001)\end{array}$ & - & - & $\begin{array}{c}0.551 \\
24.7 \\
(0.0001)\end{array}$ & $\begin{array}{c}0.406 \\
12.0 \\
(0.0001)\end{array}$ & 0.0204 \\
\hline 3 & $\begin{array}{c}0.044 \\
37.9 \\
(0.0001)\end{array}$ & $\begin{array}{c}0.008 \\
5.1 \\
(0.0001)\end{array}$ & $\begin{array}{c}0.319 \\
10.2 \\
(0.0001)\end{array}$ & $\begin{array}{c}1.027 \\
16.2 \\
(0.0001)\end{array}$ & $\begin{array}{c}0.358 \\
12.2 \\
(0.0001)\end{array}$ & $\begin{array}{c}0.081 \\
1.8 \\
(0.0667)\end{array}$ & 0.0273 \\
\hline & $\begin{array}{r}\mathrm{H}_{0}: \mathrm{F} \\
\mathrm{H}_{0}: \mathrm{FI}\end{array}$ & $\begin{array}{r}\text { treet }=\mathrm{FE} \\
+\mathrm{FE}_{\mathrm{St}} \\
\text { F-stati }\end{array}$ & $\begin{array}{l}\text { AP, F-sta } \\
* \text { POST } \\
=127.3\end{array}$ & $\begin{array}{c}\text { tic }=0.52 \\
=\text { FE }_{\text {GAAP }} \\
\text { p-value }=\end{array}$ & $\begin{array}{l}\mathrm{p} \text {-value }= \\
\mathrm{FE}_{\mathrm{GAAP}} * \mathrm{~F} \\
.0001\end{array}$ & $\begin{array}{l}4691 \\
\text { ST92, }\end{array}$ & \\
\hline
\end{tabular}

Long window stock returns are buy-and-hold returns from two days after the last quarterly earnings announcement and through the day after the current period earnings announcement, where the announcement date is obtained from the Compustat quarterly research tape. Forecast errors are defined as reported earnings per share (either Street or GAAP) minus the median consensus earnings per share forecast for the final month of the fiscal quarter, scaled by stock price. GAAP earnings are obtained from Compustat and are defined as earnings before extraordinary items and discontinued operations (item \#25) divided by average common shares outstanding (item \#61) adjusted for stock splits (item \#17). Street earnings are obtained from $I / B / E / S$ and reflect GAAP earnings per share adjusted for certain charges considered by $I / B / E / S$ to be nonrecurring. Stock price is obtained from $I / B / E / S$ as of the final month of the firm's fiscal quarter end. 
forecast errors, and for both forecast error metrics together. The purpose of the last specification is to allow a test of differences in the coefficients between the two forecast error definitions. The evidence in figure 1 indicates a clear rift between Street and GAAP earnings beginning in the early 1990s. Conversations with $I / B / E / S$ confirm that this break point corresponds to the time during which they began actively redefining "actual" earnings to exclude certain items. We allow the coefficient on forecast errors to vary across these two regimes. This is accomplished by including a time-period dummy variable, POST92, which takes the value of 1 if the observation is from 1992 or later and 0 otherwise. If there has been no change in investors' pricing of forecast errors across time, the coefficient on the interaction term should be zero. A significant positive coefficient indicates that investors view the earnings measure (either $\mathrm{EPS}_{\mathrm{Street}}$ or $\mathrm{EPS}_{\mathrm{GAAP}}$ ) to be more value relevant in the second half of the sample period.

In the separate forecast error regressions reported in table 1, both definitions of forecast error are positively related to long window returns, which is not surprising given the correlation between the two forecast error definitions of 0.78 (not reported). The explanatory power, however, is significantly greater in the $\mathrm{EPS}_{\text {Street }}$ forecast error regressions (Vuong test $\mathrm{p}$-value $=0.0063$, not reported), suggestive of investor focus on the Street's earnings number. Indeed, many Wall Street observers have suggested this result in the financial press, including Lehman Brothers accounting expert Robert Willens, who stated "My experience with investors is that they tend to pay more attention to pro forma than they do to GAAP net income." 15

In the regression including both definitions of forecast error, the coefficient on GAAP forecast errors (0.319) is statistically indistinguishable from that on Street forecast errors (0.358). An F-test cannot reject the null of equality for the two coefficient estimates, $p$-value $=0.4691$. This result suggests that in the pre-1992 portion of our sample period, investors do not reveal a strong preference for one measure over the other. Turning to the post-1992 portion of the sample period, however, we see that the coefficient estimates on the time-period interaction terms are significant for both forecast error definitions, consistent with stock returns having become more strongly associated with forecast errors (based on both Street and GAAP earnings) in the latter half of the sample period. However, the coefficient on the interaction terms in the Street forecast error regression is 1.027 relative to 0.081 for the GAAP forecast error regression. An F-test reveals that the difference between the combined forecast error coefficients is significant (e.g., $\alpha_{2}+\alpha_{3}>\alpha_{4}+\alpha_{5}$, p-value 0.0001). Thus, overall it appears that investors are displaying an increasing preference for $\mathrm{EPS}_{\text {Street }}$ over $\mathrm{EPS}_{\mathrm{GAAP}}$, despite the fact that EPS $_{\text {Street }}$ excludes an increasing proportion of expenses required under GAAP.

\footnotetext{
${ }^{15}$ See B. Alpert, "The Numbers Game: Reporting of Pro Forma Earnings Is Rising, and So Is the Debate About It," Barron's, September 11, 2000.
} 
Several recent papers focusing exclusively on GAAP earnings conclude that there has been a decline over time in the value relevance of accounting earnings (Collins, Maydew, and Weiss [1997], Francis and Schipper [1999], Chang [1999]). The evidence in this paper raises the question of how inferences in those papers might differ if the focus was on earnings followed by the Street rather than earnings under GAAP. We provide preliminary evidence on this question based on quarterly regressions of long window stock returns on quarterly earnings per share. The time-series of estimated earnings response coefficients and $\mathrm{R}^{2}$ for $\mathrm{EPS}_{\mathrm{GAAP}}$ and $\mathrm{EPS}_{\mathrm{Street}}$ are plotted in figure $2 .^{16}$

In panel A, the magnitude of the estimated earnings response coefficient gradually rises for GAAP earnings but increases sharply for Street earnings. This is consistent with the returns analyses discussed above. What is more striking is the plot of quarterly $\mathrm{R}^{2}$ in panel $\mathrm{B}$. $\mathrm{R}^{2} \mathrm{~s}$ from the regression on GAAP-based forecast errors are actually slightly higher than those using Street-based forecast errors until 1992. Around this time, the plots cross, and thereafter the $\mathrm{R}^{2}$ using Street earnings rises to approximately 0.06 while the $\mathrm{R}^{2}$ using GAAP earnings declines to approximately $0.03 .{ }^{17}$ After documenting a decline in the ability of earnings to explain returns over the 1952-1994 period, Francis and Schipper [1999] encourage future work that examines the source of changes in the value relevance of earnings. Our findings contribute to this line of work by suggesting that one explanation appears to be that investors have increased their relative focus on Street versus GAAP earnings.

\subsection{EARNINGS GROWTH CALCULATIONS AND TRENDS IN REPORTED EARNINGS}

In this section, we provide formal statistical tests of time-series trends in the difference between $\mathrm{EPS}_{\text {Street }}$ and $\mathrm{EPS}_{\mathrm{GAAP}}$. Because EPS $\mathrm{S}_{\text {Street }}$ has grown larger relative to $\mathrm{EPS}_{\mathrm{GAAP}}$, growth rates based on $\mathrm{EPS}_{\mathrm{Street}}$ may be distorted. In table 2, we investigate whether this is the case by tabulating the mean and median annual earnings growth rates based on the two different definitions of earnings. We calculate growth as $\left(\mathrm{EPS}_{\mathrm{t}}-\mathrm{EPS}_{\mathrm{t}-1}\right) / \mathrm{EPS}_{\mathrm{t}-1}$ whenever $\mathrm{EPS}_{\mathrm{t}-1}$ is positive. To minimize the influence of extreme growth due to a small denominator problem, we winsorize each growth observation at \pm 1 . Table 2 presents cross-sectional means and medians for growth computed using the two alternative earnings definitions.

The first row of table 2 is based on all observations pooled cross-sectionally across all years. The mean (median) earnings growth for the sample is

\footnotetext{
${ }^{16}$ A recent paper by Brown, Lo, and Lys [1999] concludes that researchers should be cautious when making inferences regarding the value relevance of accounting numbers based on $\mathrm{R}^{2}$. The per share data we use is subject to a scale factor similar to the one they investigate. However, we do not believe this substantially limits our inferences because any scale factor should affect the $\mathrm{R}^{2}$ of both the GAAP and Street regressions similarly.

${ }^{17}$ In the latter half of the sample period, quarterly differences in the explanatory power of Street versus GAAP earnings are significant based on Vuong tests.
} 


\section{Panel A: Earnings Response Coefficient}

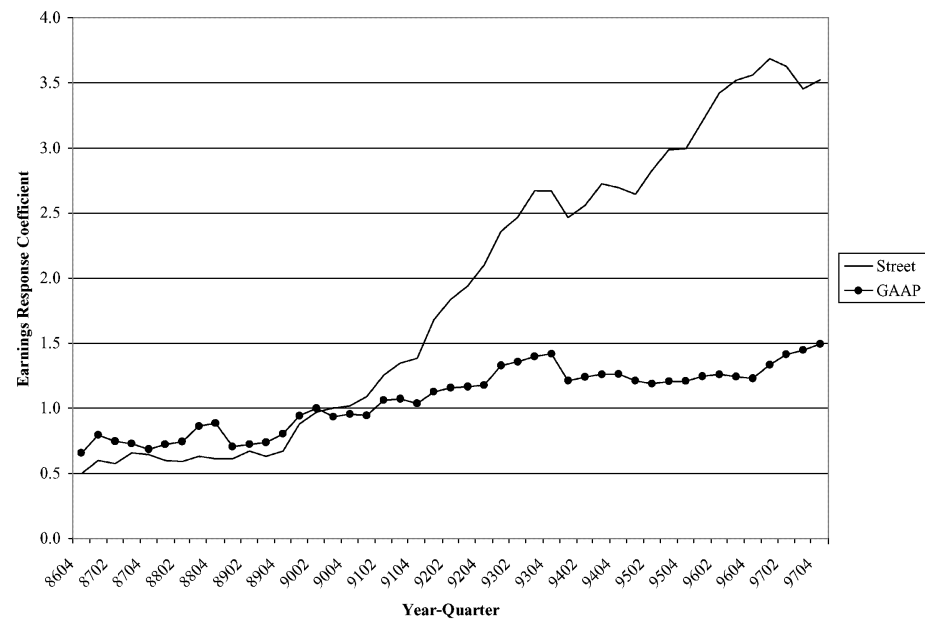

Panel B: $\mathbf{R}^{2}$

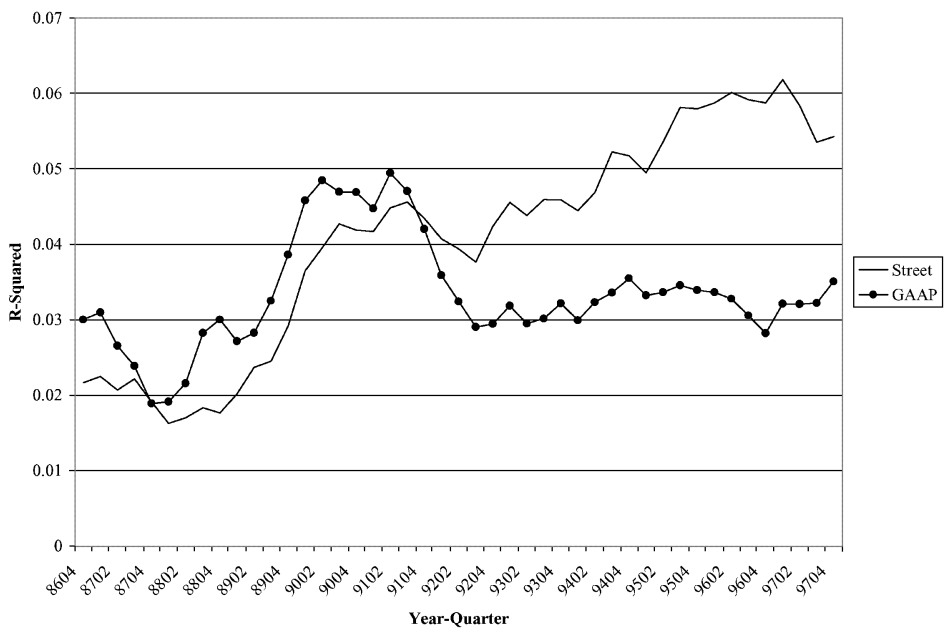

GAAP earnings are obtained from Compustat and are defined as earnings before extraordinary items and discontinued operations (data item \#25) divided by average common shares outstanding (data item \#61) adjusted for stock splits (data item \#17). Street earnings are obtained from $I / B / E / S$ and reflect GAAP earnings per share adjusted for certain charges considered by $I / B / E / S$ to be nonrecurring. Both earnings per share numbers are scaled by stock price, obtained from $I / B / E / S$ as of the final month of the firm's fiscal quarter end. Raw stock returns are obtained from CRSP and are measured beginning two days after the last quarterly earnings announcement and ending on the day after the current period earnings announcement, where the announcement date is obtained from the Compustat quarterly research tape. The plot presents two-year moving averages for the earnings response coefficients and $\mathrm{R}^{2} \mathrm{~s}$.

FIG. 2.-Time-series plots of earnings response coefficients and $\mathrm{R}^{2} \mathrm{~s}$ from quarterly crosssectional regressions of long window quarterly stock returns on Street and GAAP earnings per share, 1985-1997. 
T A B L E 2

Mean and Median Percentage Growth in Earnings Per Share for Street and GAAP Earnings Per Share, 1986-1997

\begin{tabular}{|c|c|c|c|c|c|c|}
\hline & \multicolumn{6}{|c|}{ \% Growth in Earnings Per Share } \\
\hline & \multicolumn{3}{|c|}{ Mean } & \multicolumn{3}{|c|}{ Median } \\
\hline & Street & GAAP & p-value & Street & GAAP & $\mathrm{p}$-value \\
\hline All years & 7.1 & 4.9 & 0.0001 & 11.1 & 9.5 & 0.0001 \\
\hline \multicolumn{7}{|c|}{ By Quarter } \\
\hline 1 & 7.6 & 6.7 & 0.1212 & 10.5 & 9.6 & 0.0466 \\
\hline 2 & 6.8 & 5.4 & 0.0135 & 10.9 & 9.5 & 0.0008 \\
\hline 3 & 7.6 & 5.5 & 0.0003 & 11.1 & 9.7 & 0.0007 \\
\hline 4 & 6.5 & 2.2 & 0.0001 & 11.1 & 9.1 & 0.0001 \\
\hline \multicolumn{7}{|l|}{ By year } \\
\hline 1986 & -3.8 & -1.1 & 0.0346 & 2.2 & 3.5 & 0.1870 \\
\hline 1987 & 6.4 & 7.1 & 0.5902 & 10.5 & 10.0 & 0.6651 \\
\hline 1988 & 14.1 & 13.5 & 0.6680 & 16.1 & 15.1 & 0.2949 \\
\hline 1989 & 0.2 & 0.5 & 0.7754 & 5.7 & 6.1 & 0.6248 \\
\hline 1990 & -4.9 & -5.7 & 0.4407 & 0.0 & 1.0 & 0.0663 \\
\hline 1991 & -5.3 & -6.2 & 0.4270 & 0.0 & 0.0 & 0.5448 \\
\hline 1992 & 8.5 & 7.5 & 0.3747 & 11.1 & 10.9 & 0.4918 \\
\hline 1993 & 10.4 & 7.7 & 0.0048 & 12.1 & 11.3 & 0.2145 \\
\hline 1994 & 14.5 & 10.9 & 0.0001 & 15.2 & 13.9 & 0.0524 \\
\hline 1995 & 11.5 & 6.9 & 0.0001 & 13.7 & 11.4 & 0.0001 \\
\hline 1996 & 10.0 & 6.1 & 0.0001 & 13.8 & 11.9 & 0.0004 \\
\hline 1997 & 10.2 & 6.4 & 0.0001 & 13.8 & 12.1 & 0.0007 \\
\hline
\end{tabular}

Earnings growth is calculated for both Street and GAAP earnings per share (EPS) as $\left(\mathrm{EPS}_{\mathrm{t}}-\mathrm{EPS}_{\mathrm{t}-1}\right) /$ EPS $_{\mathrm{t}-1}$ whenever $\mathrm{EPS}_{\mathrm{t}-1}$ is positive and is winsorized at $+/-1$. GAAP earnings are obtained from Compustat and are defined as earnings before extraordinary items and discontinued operations (item \#25) divided by average common shares outstanding (item \#61) adjusted for stock splits (item \#17). Street earnings are obtained from $I / B / E / S$ and reflect GAAP earnings per share adjusted for certain charges considered by $I / B / E / S$ to be nonrecurring. The p-values for the mean percentage growth figures are based on a twosided t-test for differences of means. The p-values for the median percentage growth figures are based on a Z-statistic for a 2-sample test of medians.

$7.1 \%(11.1 \%)$ based on EPS $_{\text {Street }}$ and $4.9 \%(9.5 \%)$ based on EPS $_{\text {GAAP. }}$ The mean and median differences are both highly statistically significant. Turning to the middle section of table 2, we present growth statistics by fiscal quarter. With the exception of quarter 1 , growth calculations based on $\mathrm{EPS}_{\text {Street }}$ are statistically larger than those based on $\mathrm{EPS}_{\mathrm{GAAP}}$. The difference is especially pronounced in the fourth quarter, where the mean growth based on $\mathrm{EPS}_{\mathrm{Street}}$ is approximately three times that calculated based on EPS $_{\mathrm{GAAP}}$. The last section of the table shows the pattern in growth calculations across years. Note that the growth statistics based on the alternative definitions of earnings track each other reasonably well up until 1993, when the divergence becomes noticeable and is statistically significant based on test of means and medians. ${ }^{18}$

\footnotetext{
${ }^{18}$ These results corroborate the use of 1992 as the break-point in the long window earningsreturns association tests in the previous section.
} 
T A B L E 3

Time Trend Regressions of the Difference Between Street and GAAP Earnings, 1985-1997 (t-statistics and (p-values) under coefficient estimates)

\begin{tabular}{|c|c|c|c|c|}
\hline \multicolumn{5}{|c|}{$\mathrm{DIFF}=\alpha_{0}+\alpha_{1} \mathrm{YEAR}+\varepsilon$} \\
\hline & $\mathrm{N}$ & Intercept & YEAR & $\mathrm{R}^{2}$ \\
\hline \multicolumn{5}{|l|}{ Quarter } \\
\hline \multirow[t]{3}{*}{1} & 24,470 & -0.0004 & 0.0002 & 0.0004 \\
\hline & & -0.9 & 3.3 & \\
\hline & & $(0.3540)$ & $(0.0011)$ & \\
\hline \multirow[t]{3}{*}{2} & 27,688 & -0.0014 & 0.0004 & 0.0018 \\
\hline & & -3.2 & 7.2 & \\
\hline & & $(0.0016)$ & $(0.0001)$ & \\
\hline \multirow[t]{3}{*}{3} & 28,214 & -0.0004 & 0.0003 & 0.0011 \\
\hline & & -0.9 & 5.5 & \\
\hline & & $(0.3546)$ & $(0.0001)$ & \\
\hline \multirow[t]{3}{*}{4} & 28,492 & 0.0011 & 0.0006 & 0.0021 \\
\hline & & 1.7 & 7.6 & \\
\hline & & $(0.0835)$ & $(0.0001)$ & \\
\hline \multirow[t]{3}{*}{ All Quarters } & 108,864 & -0.0000 & 0.0004 & 0.0014 \\
\hline & & -0.1 & 12.1 & \\
\hline & & $(0.8918)$ & $(0.0001)$ & \\
\hline
\end{tabular}

DIFF is the difference between Street and GAAP earnings per share, scaled by stock price. GAAP earnings are obtained from Compustat and are defined as earnings before extraordinary items and discontinued operations (item \#25) divided by average common shares outstanding (item \#61) adjusted for stock splits (item \#17). Street earnings are obtained from $I / B / E / S$ and reflect GAAP earnings per share adjusted for certain charges considered by $I / B / E / S$ to be nonrecurring. Stock price is obtained from $I / B / E / S$ as of the final month of a firm's fiscal quarter end. YEAR is equal to the fiscal year minus 1985 .

We define a variable DIFF $=\left(E P S_{\text {Street }}-E P S_{G A A P}\right) /$ Price. Table 3 presents the results of regressions of DIFF on a time trend variable, YEAR, equal to the fiscal year of the observation minus 1985. We estimate the regression separately for each fiscal quarter. The intercept represents the average level of the difference between Street and GAAP earnings in 1985, while the coefficient on YEAR represents the average annual increase in that difference. With the exception of quarter 2, intercepts are close to zero, consistent with figure 1 . The coefficient on YEAR is positive and highly statistically significant for each quarter, with coefficients ranging from 0.0002 in the first quarter to 0.0006 in the fourth quarter. To gauge the economic significance of these differences, consider the fourth quarter. In the fourth quarter, table 3 indicates that DIFF is approximately 0.0083 in the most recent sample year $(=0.0011+0.0006 *(1997-1985))$. For a firm with an annual $\mathrm{P} / \mathrm{E}$ ratio in the 20-25 range, reasonable for the period, a value for DIFF of 0.0083 implies EPS Street $_{\text {exceeds the EPS }}$ GAAP by 17-21\%. Thus, consistent with our first prediction, the difference between Street and GAAP earnings has been gradually growing over the last decade, and the magnitude of the difference is economically significant.

\subsection{CONTEMPORANEOUS TRENDS IN SPECIAL ITEMS}

Compustat's "special items" category captures a subset of the charges that are routinely excluded from EPS $_{\text {Street }}$. Thus, the increasing rift 


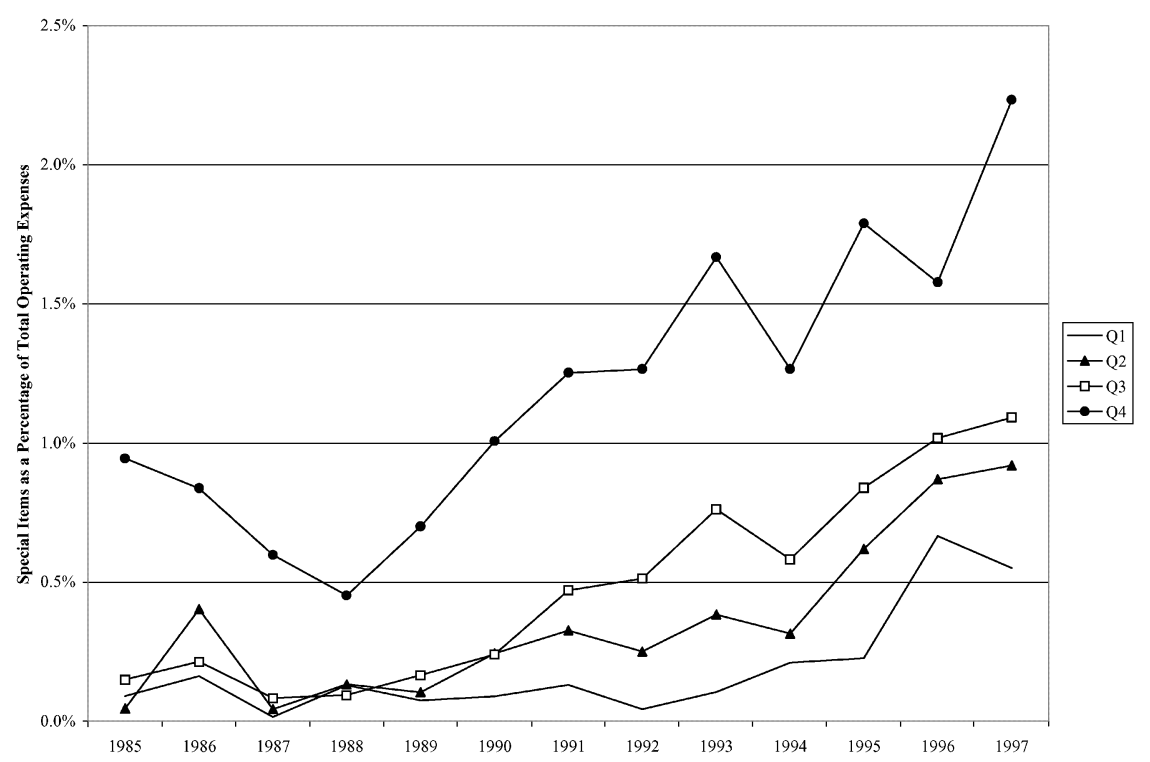

Special items (data item \#32) and total operating expenses, defined as the difference between sales (data item \#2) and pretax income (data item \#23), are obtained from the Compustat quarterly research tapes.

FIG. 3.-Quarterly time-series plots of cross-sectional means of special items as a percentage of total operating expenses, 1985-1997.

between $\mathrm{EPS}_{\text {Street }}$ and $\mathrm{EPS}_{\mathrm{GAAP}}$ is consistent with the increases in special items reported in recent years (Elliott and Hanna [1996], Collins, Maydew, and Weiss [1997]). In this subsection, we first provide an analysis of the magnitude and frequency of special items over our sample period. We then examine trends in the extent to which special items are excluded from $\mathrm{EPS}_{\text {Street }}$ over our sample period.

Figure 3 presents the cross-sectional mean of special items (as a percentage of total operating expenses), and figure 4 shows the percentage of firms recording positive or negative special items over the sample period. The figures demonstrate that the magnitude and frequency of special items have continued increasing beyond the period studied in the papers referenced above (e.g., through 1993-1994). For example, in recent years, figure 3 indicates that mean special items range between $0.5 \%$ and $1 \%$ of total operating expenses for the first through third quarters, and around $2 \%$ of total operating expenses for the fourth quarter, all in excess of the levels in 1994. More striking, figure 4 indicates that by 1997, approximately 1 in 10 firms recorded a negative special item in each of the first three fiscal quarters, and over 1 in 5 firms recorded negative special items in the fourth quarter. In unreported time-trend regressions, the patterns evident in figures 3 and 4 are statistically significant. Overall, the figures suggest that firms' use of special items does not appear to be a temporary or stable phenomenon. 


\section{Panel A: Quarter 1}

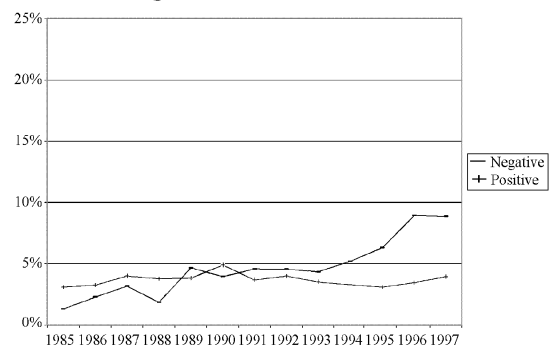

Panel C: Quarter 3

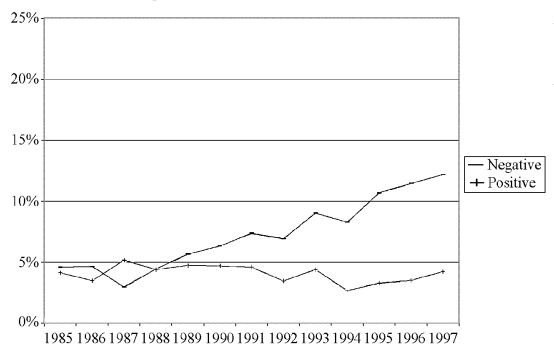

Panel B: Quarter 2

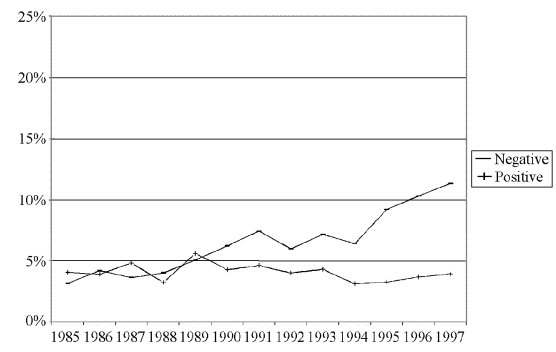

Panel D: Quarter 4

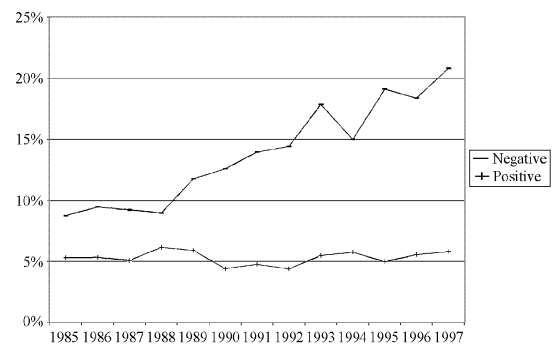

Special items (data item \#32) are obtained from the Compustat quarterly research tapes.

FIG. 4.-Quarterly time-series plots of percentages of firms recording positive and negative special items, 1985-1997.

\subsection{LINKING RECENT TRENDS IN SPECIAL ITEMS TO THE INCREASING DIFFERENCES BETWEEN STREET AND GAAP EARNINGS}

To specifically link the trends in special items and differences in Street and GAAP earnings noted above, we investigate differences in earnings partitioned by the sign of special items. In table 4 , we measure the extent to which special items are excluded from EPS $_{\text {Street }}$ by regressing the differences (DIFF) on special items (SI) and an interaction term between special items and the variable YEAR. To interpret the coefficients, note differences between Street earnings and GAAP earnings are after-tax, but special items are stated on a pre-tax basis. Assuming a tax rate of approximately $35 \%$, the expected coefficient on special items is negative 0.65 if $I / B / E / S$ has

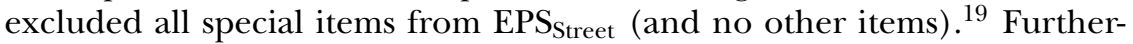
more, if the treatment of special items by $I / B / E / S$ has been consistent over the sample period, the coefficient on the interaction term should be zero. This should be true regardless of the increase in special items documented

\footnotetext{
${ }^{19}$ The predicted coefficient is negative because negative special items should accompany a positive value for $\mathrm{EPS}_{\text {Street }}$-EPS $_{\mathrm{GAAP}}$.
} 
T A B L E 4

Tests for the Ability of Special Items to Explain Differences Between Street and GAAP Earnings Per Share, 1985-1997 (t-statistics and (p-values) under coefficient estimates)

\begin{tabular}{|c|c|c|c|c|c|c|}
\hline \multicolumn{7}{|c|}{$\mathrm{DIFF}=\alpha_{0}+\alpha_{1} \mathrm{SI}+\alpha_{2} \mathrm{YEAR}+\alpha_{3} \mathrm{SI} * \mathrm{YEAR}+\varepsilon$} \\
\hline & $\mathrm{N}$ & Intercept & SI & YEAR & $\mathrm{SI} * \mathrm{YEAR}$ & Adj. $R^{2}$ \\
\hline \multicolumn{7}{|l|}{ Quarter } \\
\hline \multirow[t]{2}{*}{1} & 24,470 & -0.000 & -0.066 & 0.0000 & -0.057 & 0.0888 \\
\hline & & $\begin{array}{l}-0.0 \\
(0.9889)\end{array}$ & $\begin{array}{l}-1.7 \\
(0.0937)\end{array}$ & $\begin{array}{l}1.0 \\
(0.3152)\end{array}$ & $\begin{array}{r}-13.5 \\
(0.0001)\end{array}$ & \\
\hline \multirow[t]{2}{*}{2} & 27,688 & -0.002 & -0.496 & 0.0003 & -0.011 & 0.1789 \\
\hline & & $\begin{array}{l}-4.8 \\
(0.0001)\end{array}$ & $\begin{aligned}-32.3 \\
(0.0001)\end{aligned}$ & $\begin{array}{l}6.2 \\
(0.0001)\end{array}$ & $\begin{array}{l}-5.9 \\
(0.0001)\end{array}$ & \\
\hline \multirow[t]{2}{*}{3} & 28,214 & -0.000 & -0.242 & 0.0001 & -0.047 & 0.2941 \\
\hline & & $\begin{array}{l}-0.9 \\
(0.3684)\end{array}$ & $\begin{aligned}-16.0 \\
(0.0001)\end{aligned}$ & $\begin{array}{l}1.5 \\
(0.1432)\end{array}$ & $\begin{array}{l}-26.4 \\
(0.0001)\end{array}$ & \\
\hline \multirow[t]{2}{*}{4} & 28,492 & -0.000 & -0.336 & 0.0002 & -0.037 & 0.3214 \\
\hline & & $\begin{array}{l}-0.8 \\
(0.4306)\end{array}$ & $\begin{array}{l}-30.0 \\
\quad(0.0001)\end{array}$ & $\begin{array}{l}2.9 \\
(0.0027)\end{array}$ & $\begin{array}{l}-26.7 \\
\quad(0.0001)\end{array}$ & \\
\hline \multirow[t]{2}{*}{ All Quarters } & 108,864 & -0.001 & -0.345 & 0.0002 & -0.034 & 0.2564 \\
\hline & & -2.4 & -49.2 & 5.9 & -40.3 & \\
\hline
\end{tabular}

DIFF is the difference between Street and GAAP earnings per share, scaled by stock price. GAAP earnings are obtained from Compustat and are defined as earnings before extraordinary items and discontinued operations (item \#25) divided by average common shares outstanding (item \#61) adjusted for stock splits (item \#17). Street earnings are obtained from $I / B / E / S$ and reflect GAAP earnings per share adjusted for certain charges considered by $I / B / E / S$ to be nonrecurring. Stock price is obtained from $I / B / E / S$ as of the final month of a firm's fiscal quarter end. YEAR is equal to the fiscal year minus 1985.

above. However, as noted in section 3, there are numerous other charges that we do not specifically consider, and to the extent there are other charges excluded by $I / B / E / S$ but not captured within Compustat "special items," the coefficient estimate will be biased towards zero and the explanatory power of the regression will be reduced. ${ }^{20}$

The results in table 4 are consistent our predictions. First, the coefficient on special items is negative in all four fiscal quarters. This indicates that $I / B / E / S$ has filtered some special items from earnings as far back as 1985 . More importantly, the coefficient on the interaction term is also consistently negative and significant, indicating that $I / B / E / S$ has gradually excluded an increasing proportion of special items from the Street definition of earnings. This result is consistent with our third prediction. The tendency to exclude special items from Street earnings is greater now than in the past. To gauge the economic significance of these results, in the last year of the sample it appears that, on average, the difference between fourth quarter $I / B / E / S$ and Compustat earnings is approximately $78 \%$ of special items $(\approx \mid-0.336+$ $(1997-1985) *(0.0002-0.037) \mid)$. Thus, it appears that $I / B / E / S$ is indeed

\footnotetext{
${ }^{20}$ Philbrick and Ricks [1991] examine detailed financial statements for the 60 firm-quarter observations in their sample with the largest differences between Compustat and Value Line earnings per share, and find that in 57 cases, the differences were due to write-offs or similar charges that were not coded as "special items" by Compustat.
} 
excluding special items from their definition of earnings, as they claim, but that the treatment has not been consistent across years.

Although the adjusted $\mathrm{R}^{2} \mathrm{~s}$ of the regressions in table 4 are relatively high, these simple regressions surely omit a number of other factors that also contribute to the variation in differences in the two earnings definitions. Thus, we emphasize that although these results are based on special items, the trend in the exclusion of special items is likely generalizable to other excluded costs. In unreported analyses, we estimate the regression of differences between Street and GAAP earnings on special items and time trend variables using annual data, for which Compustat provides more refined information on "other charges." In addition to special items, we also include amortization expense, research and development expense, and nonoperating income as explanatory variables in the regressions. In addition to the importance of special items, we find that differences between Street and GAAP earnings are also explained by all three of these additional charges, although the incremental explanatory power is moderate. Moreover, we find that for amortization expense, the coefficient on the interaction term is statistically significant. Thus, similar to the exclusion of special items by the Street, it appears that the exclusion of amortization expense from earnings followed by the Street has also been gaining popularity, consistent with anecdotal evidence.

\subsection{ANALYSIS OF TEMPORAL CHANGES IN ALTERNATIVELY DEFINED FORECAST ERRORS}

The above analyses suggest that inferences in research that uses $I / B / E / S$ actuals when computing forecast errors may be contaminated by the changing treatment of certain GAAP expenses by analyst databases over time. For example, recent studies suggest that analysts have become less optimistic in their forecasts of earnings in recent years (e.g., Matsumoto [2000], Brown [2001]). To the extent that the tracking services have redefined the "actual" earnings upon which forecast errors are calculated, those studies may reflect the changing definition of Street earnings. To provide evidence on this possibility, we investigate the characteristics of forecast errors computed using both EPS $_{\text {Street }}$ and EPS $_{\text {GAAP. }}$.

Figure 5 presents forecast errors by the sign of special items and definition of realized earnings. In both panels of figure 5, it is evident that when a firm records a negative special item, the forecast is optimistic (i.e., forecast error is negative) regardless of realized earnings definition. Moreover, both definitions of forecast errors reveal some attenuation of negative forecast errors over the sample period. However, the decline in optimism is sharply pronounced when forecast errors are defined relative to EPS $_{\text {Street }}$ (panel B).

Matsumoto [2000] also finds an attenuation of negative forecast errors over time. However, she interprets the decline in optimism as evidence of management's downward guidance of analysts' forecasts such that management can report earnings that meet or beat the analysts' forecasts. 


\section{Panel A: Mean forecast errors based on GAAP earnings}

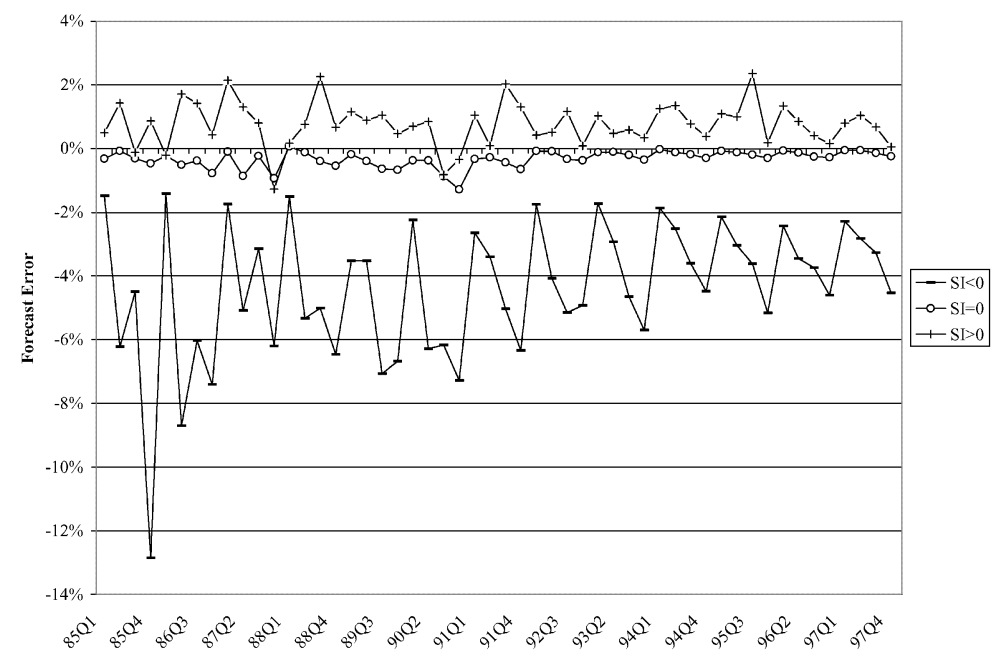

\section{Panel B: Mean forecast errors based on Street earnings}

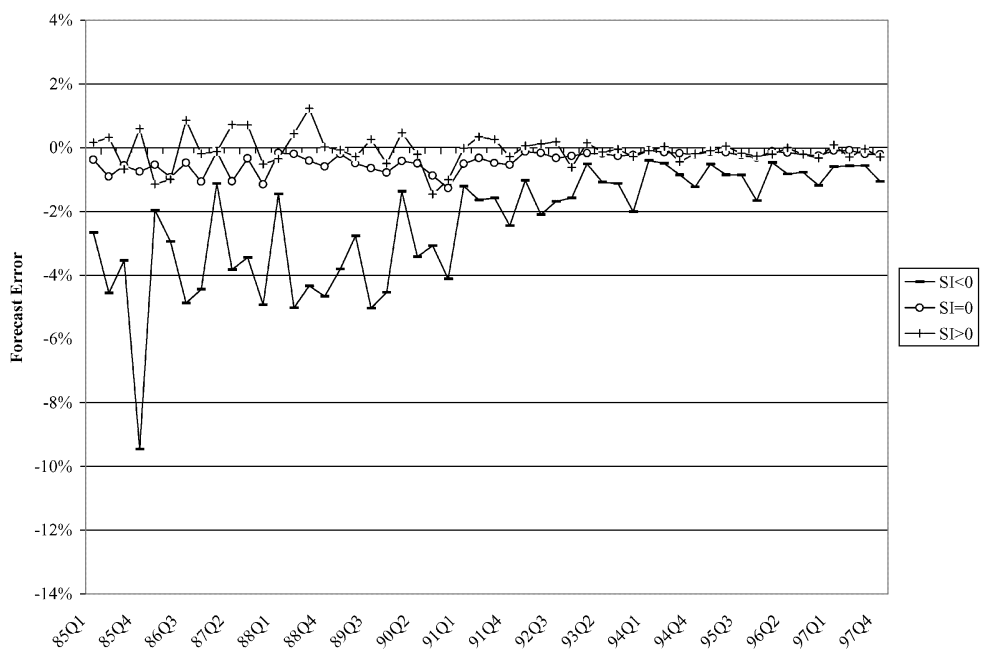

Forecast errors are defined as reported earnings per share (either Street or GAAP) minus the median consensus earnings per share forecast for the final month of the fiscal quarter, scaled by stock price. GAAP earnings are obtained from Compustat and are defined as earnings before extraordinary items and discontinued operations (item \#25) divided by average common shares outstanding (item \#61) adjusted for stock splits (item \#17). Street earnings are obtained from $I / B / E / S$ and reflect GAAP earnings per share adjusted for certain charges considered by $I / B / E / S$ to be nonrecurring. Stock price is obtained from $I / B / E / S$ as of the final month of the firm's fiscal quarter end. Special items (data item \#32) are obtained from the Compustat quarterly research tapes.

FIG. 5.-Time-series plots of mean street-based and GAAP-based forecast errors as a percentage of stock price, partitioned by the sign of special items, 1985-1997. 
In her study, the forecast error is computed relative to the earnings provided by Zacks, similar to our EPS $_{\text {Street }}$ computation. An alternative interpretation, suggested by our results, is that the decline in optimism is due to an overtime increase in the earnings per share reported by the analyst tracking service (as they have gradually removed certain items), rather than downward pressure from management on forecasted earnings per share. We are inclined to believe that the documented decline in optimism reflects both phenomena. Thus, we interpret the collective evidence as complementary, rather than mutually exclusive and argue that the documented decline in analysts' forecast optimism is due, at least in part, to a redefining of Street earnings over the past decade.

\subsection{ORIGINATION OF THE EMPHASIS ON STREET EARNINGS}

Anecdotally, it appears that the redefining of earnings is originating with firm managers. However, an alternative is that the analysts and/or the analyst tracking services are increasingly taking it upon themselves to remove certain charges from reported earnings. To investigate this issue further, we examine a sample of earnings announcement disclosures. The disclosures are obtained from newswires, which contain press releases prepared by firm managers. We limit our analysis to observations where Street earnings exceed GAAP earnings. Thus, we are asking the question, conditional on Street earnings exceeding GAAP earnings, does management emphasize the Street number over the GAAP number? If so, we expect to find an increase in the frequency with which managers discuss Street earnings and a relative displacement of the discussion of GAAP earnings within the announcement.

The sample is selected from two early years of our sample period (19861987) and the two years immediately following our sample period (19981999). From each of these periods, we randomly select 50 earnings announcements per fiscal quarter in each of the two subperiods from the set of announcements for which $\mathrm{EPS}_{\mathrm{Street}}>\mathrm{EPS}_{\mathrm{GAAP}}$, yielding 400 total announcements. We obtain the 400 corresponding earnings announcement press releases from the Dow Jones News Retrieval Service. We code which earnings number is discussed first, the paragraph in which it is discussed (PRESENT $1=1$ if presented in paragraph 1 , PRESENT1 $=2$ if discussed in paragraph 2, etc.), and likewise for the earnings number discussed second (PRESENT2), when applicable.

Panel A of table 5 tabulates the frequency of combinations of Street and GAAP earnings discussed by managers in each time period. Three items are noteworthy. First, approximately 83 percent $(n=165)$ of the earnings announcements from the 1986-1987 period discussed GAAP earnings only, while just 28 percent $(n=56)$ of the earnings announcements for the 19981999 period discussed GAAP earnings only (difference significant at $<0.001$ level). Second, there is a large increase in the number of earnings announcements that discuss dual measures of earnings. Whereas 18 percent $(n=22+13)$ of the earnings announcements from the earlier period 
T A B L E 5

Analysis of 400 Corporate Earnings Announcements for Evidence of a Change in Preference Between Discussing Street and GAAP Earnings for Two Subperiods, 1986-1987 and 1998-1999

\begin{tabular}{|c|c|c|c|c|c|}
\hline \multirow[b]{2}{*}{ Period } & \multicolumn{4}{|c|}{ Order of earnings per share presentation } & \multirow[b]{2}{*}{ All } \\
\hline & GAAP only & $\begin{array}{c}\text { GAAP then } \\
\text { Street }\end{array}$ & $\begin{array}{c}\text { Street then } \\
\text { GAAP }\end{array}$ & Street only & \\
\hline \multicolumn{6}{|c|}{ Panel A: Tabulation of frequencies of combinations of earnings per share numbers discussed } \\
\hline $1986-1987$ & $\begin{array}{c}165 \\
(82.5 \%)\end{array}$ & $\begin{array}{c}22 \\
(11.0 \%)\end{array}$ & $\begin{array}{c}13 \\
(6.5 \%)\end{array}$ & $\begin{array}{c}0 \\
(0.0 \%)\end{array}$ & $\begin{array}{c}200 \\
(100 \%)\end{array}$ \\
\hline 1998-1999 & $\begin{array}{c}57 \\
(28.5 \%)\end{array}$ & $\begin{array}{c}56 \\
(28.0 \%)\end{array}$ & $\begin{array}{c}84 \\
(42.0 \%)\end{array}$ & $\begin{array}{c}3 \\
(1.5 \%)\end{array}$ & $\begin{array}{c}200 \\
(100 \%)\end{array}$ \\
\hline Total & 222 & 78 & 97 & 3 & 400 \\
\hline Z-statistic & $20.1^{* *}$ & $7.7^{* *}$ & $20.4^{* *}$ & - & - \\
\hline$\chi^{2}$ & - & - & - & - & $122.3^{* *}$ \\
\hline
\end{tabular}

Panel B: Mean Paragraph in which GAAP and Street earnings per share are presented first

\begin{tabular}{|c|c|c|c|c|c|}
\hline \multicolumn{6}{|l|}{ 1986-1987 } \\
\hline PRESENT1 & 2.2 & 2.5 & 1.5 & - & 2.2 \\
\hline PRESENT2 & - & 3.4 & 2.3 & - & 3.0 \\
\hline Spread & - & $0.9^{*}$ & 0.8 & - & \\
\hline t-test for differences & & & 0.0 & & \\
\hline \multicolumn{6}{|l|}{ 1998-1999 } \\
\hline PRESENT1 & 2.7 & 2.2 & 1.9 & 3.3 & 2.2 \\
\hline PRESENT2 & - & 2.7 & 4.0 & - & 3.4 \\
\hline Spread & - & 0.5 & $2.1^{*}$ & - & \\
\hline t-test for differences & & & $3.8^{* *}$ & & \\
\hline
\end{tabular}

Fifty earnings announcements for each of the first through fourth quarters in each subperiod are obtained from Dow Jones News Retrieval Service. PRESENT1 (PRESENT2) is the paragraph in which the first (second, when applicable) earnings per share figure is discussed. t-tests are 2-tailed. Z-tests are based on binomial tests of differences in instances for the 1998-1999 subperiod, except for the "Street Only" instance for which the zero instances in the 1986-1987 make this test invalid.

${ }^{*}$ Denotes significance at the 0.01 level.

** Denotes significance at the 0.001 level.

discuss both Street and GAAP earnings, 70 percent $(n=56+84)$ of the earnings announcements from the later period discuss both definitions (difference significant at $<0.001$ level, not tabulated). Finally, conditional on discussing both Street and GAAP earnings, there is a marked change in the order in which managers discuss both measures of earnings. In the earlier period, GAAP is discussed prior to Street earnings in 22 of $35(63 \%)$ such announcements. In the later period, the tendency to first disclose GAAP earnings reverses and managers discuss Street earnings before GAAP earnings in 84 of $140(60 \%)$ of such announcements (difference significant at $<0.001$ level). Overall, a chi-square test rejects the null hypothesis that the composition of earnings per share presentation is the same across the two periods ( $\mathrm{p}$-value $<0.001$ ).

The evidence in panel A suggests that managers have stepped up their efforts to highlight Street earnings relative to GAAP earnings, but does not give an indication of the relative displacement of GAAP earnings within the announcements. Panel B of table 5 presents formal evidence on the ordering 
of earnings disclosures within earnings announcements. We tabulate the means of PRESENT1 and PRESENT2. Most earnings figures are presented in the first two or three paragraphs. In the 1986-1987 period, the mean paragraph in which earnings are first discussed is 2.5 when GAAP is presented first and 1.5 when Street is presented first. In this period, the spread in the mean paragraph between the first and second earnings figure discussed is 0.9 (significant, based on two-tailed t-tests of the difference in paragraph numbers) when GAAP is presented first, and 0.8 (not significant) when Street is presented first. However, the difference between these two spreads is not significant, indicating that the ordering of GAAP and Street earnings when both are presented reveals no systematic pattern for the earlier period. In contrast, for 1998-1999, when Street earnings are presented first there is a significant mean spread of 2.1 paragraphs (significant) between PRESENT1 and PRESENT2, and this spread is significantly larger than the spread of 0.5 paragraphs when GAAP precedes Street earnings.

Overall, the evidence indicates that in recent periods, managers emphasize Street earnings earlier than GAAP earnings within press releases. Although our tests cannot conclusively rule out the possibility that managers are responding to pressures from analysts to partition earnings into permanent and transitory components, we believe that the evidence we present combined with our readings of earnings announcements and statements in the financial press indicate that managers are proactive in the promotion of Street earnings.

\section{Conclusion and Implications}

In this paper, we investigate two alternative definitions of accounting earnings: earnings computed under GAAP and a modified Street version of accounting earnings that excludes various items recorded under GAAP. For the period 1986-1997, we document a marked increase in the exclusion of significant expenses from the earnings reported by analyst tracking services, and a corresponding increase in firms specifically identifying large portions of their expenses as nonrecurring. This change in the reporting environment has resulted in a growing disparity between earnings under GAAP and earnings followed by the Street. We also show that investors display an increasing preference for the modified version of earnings reported by the analyst tracking services as opposed to earnings as dictated by GAAP.

Our findings are important to the interpretation of other research in the literature. To the extent that managers have been successful in persuading analysts and investors to ignore certain charges and these are reflected in research databases, the decline in analysts' optimism documented in recent research is due, at least in part, to the redefining of Street earnings rather than management guidance of analysts' forecasts. In this respect, our findings are relevant to any research that draws inferences based on a time-series of forecast errors. Additionally, we present evidence pertinent to prior research on changes in the value relevance of earnings over time. We find that 
both the earnings response coefficient and regression $R^{2} s$ increase significantly for Street earnings. This suggests that although the value relevance of reported earnings may have declined relative to book values (Collins, Maydew, and Weiss [1997]), the value relevance of Street earnings appears to have increased significantly.

A long history of research investigates the ability of managers to manipulate or manage earnings. Our results have implications for this work if the phenomenon we document reflects opportunistic behavior by managers rather than rational screening of transitory items by investors. Although the analysis here focuses exclusively on differences in earnings due to items flagged by Compustat as "special items," recent trends in financial reporting suggest that managers and analysts are extending the list of "ignored" expenses to include other expenses. For example, there is a recent and growing trend in the reporting of "cash earnings," equal to earnings adjusted upwards to exclude goodwill amortization. ${ }^{21}$ Our results suggest that investors currently appear to be willing to accept these modified definitions of earnings. Moreover, preliminary findings discussed in section 4.5 suggest that our results are generalizable beyond special items, but that future work in this area is warranted.

\section{REFERENCES}

Abarbanell, J., AND R. LehaVy. "Differences in Commercial Database Reported Earnings." Working paper, University of North Carolina and University of California, Berkeley, 2000.

Bagnoli, M.; R. EsKeW; AND S. G. WATTs. "Earnings Surprises When Firms Choose What Matters.” Working paper, Purdue University, July 2001.

BALL, R. J., AND P. BROWN. "An Empirical Evaluation of Accounting Income Numbers." Journal of Accounting Research (Autumn 1968): 159-78.

BarneA, A.; J. Ronen; AND S. SADAN. "The Implementation of Accounting Objectives: An Application to Extraordinary Items.” The Accounting Review (January 1975): 58-68.

BARNEA, A.; J. Ronen; AND S. SADAN. "Classificatory Smoothing of Income with Extraordinary Items.” The Accounting Review (January 1976): 110-22.

Brown, L. D. "A Temporal Analysis of Earnings Surprises: Profits Versus Losses.” Journal of Accounting Research (Autumn 2001): 221-41.

BROWN, L. D., AND K. SIVAKUMAR. “Comparing the Quality of Three Earnings Measures.” Working paper, Georgia State University, May 2001.

BROWN, S.; K. LO; AND T. LYS. "Use of $\mathrm{R}^{2}$ in Accounting Research: Measuring Changes in Value Relevance Over the Last Four Decades." Journal of Accounting and Economics (December 1999): 83-116.

Burgstahler, D.; J. Jiambalvo; And T. Shevlin. "Time-series Properties and Pricing of the Special Items Component of Earnings.” Working paper, University of Washington, May 1999. CHAng, J. "The Decline in Value Relevance of Earnings and Book Values." Working paper, Harvard University, February 1999.

${ }^{21}$ First Call is now accepting forecasts of "cash earnings" that exclude amortization of goodwill, for instance. See a concurrent paper by Bagnoli, Eskew, and Watts [2001] that demonstrates persistent positive forecast errors for a subset of firms that have convinced analysts to forecast "cash" earnings per share. See also "No Accounting for the Net? Profit Issue Sparks Conflict," Laura Johannes, The Wall Street Journal, May 19, 2000, p. C1, C17. 
Collins, D. W.; E. L. MAYDEW; AND I. S. WeISs. "Changes in the Value-Relevance of Earnings and Book Values over the Past Forty Years." Journal of Accounting and Economics (December 1997): 39-68.

ELliotT, J., AND J. D. HANNA. "Repeated Accounting Write-offs and the Information Content of Earnings.” Journal of Accounting Research (Supplement 1996): 135-55.

FrANCIS, J., AND K. SCHIPPER. "Have Financial Statements Lost Their Relevance?” Journal of Accounting Research (Autumn 1999): 319-52.

Healy, P. M., AND J. M. WAHLEN. "A Review of the Earnings Management Literature and its Implications for Standard Setting." Forthcoming in Accounting Horizons (1999).

$I / B / E / S$. "The $I / B / E / S$ Glossary, A Guide to Understanding $I / B / E / S$ Terms and Conventions." $I / B / E / S$ International Inc. (1996).

KASZNIK, R., AND B. LEV. "To Warn or not to Warn: Management Disclosures in the Face of an Earnings Surprise.” The Accounting Review (January 1995): 113-34.

KinneY, M., AND R. TREZEVAnT. "The Use of Special Items to Manage Earnings and Perceptions." Journal of Financial Statement Analysis (Fall 1997): 45-59.

KINNEY, W.; D. BURGSTAhlER; AND R. MARTIN. "The Materiality of Earnings Surprise.” Working paper, University of Texas, University of Washington, and Indiana University, January 2000.

Matsumoto, D. A. "Management's Incentives to Influence Analysts' Forecasts.” Working paper, University of Washington, 2000.

PHILBRICK, D. R., AND W. E. RICKS. "Using Value Line and IBES Analyst Forecasts in Accounting Research.” Journal of Accounting Research (Autumn 1991), 397-417.

Richardson, S.; S. H. TEOH; AND P. WYSOCKI. "Tracking Analysts' Forecasts Over the Annual Earnings Horizon: Are Analysts' Forecasts Optimistic or Pessimistic?” Working paper, University of Michigan, 2000.

SCHRAND, C. M., AND B. R. WALTHER. "Strategic Benchmarks in Earnings Announcements: The Selective Disclosure of Prior-Period Earnings Components." The Accounting Review (April 2000): 151-77.

SKINNER, D. J. "Earnings Disclosures and Stockholder Lawsuits." Journal of Accounting and Economics (November 1997): 249-82.

SkINNER, D. J., AND R. G. SLOAN. "Earnings Surprises, Growth Expectations, and Stock Returns: Don't Let an Earnings Torpedo Sink Your Portfolio.” Working paper, University of Michigan, July 1999. 